\author{
한우 ADSF/resistin 유전자의 단일 염기 다형과 육질관련형질 \\ 상관 분석 \\ 박지애* • 강혜경* • 채은진* • 서강석** • 김상훈*** • 윤철희**** • 문양수* \\ 진주산업대학교 동물생명과학과*, 축산과학원**, 경희대학교 생물학과***, \\ 서울대학교 식품동물생명공학부****
}

\title{
Analysis of the ADSF/resistin Gene Polymorphism Associated with Carcass Traits in Hanwoo
}

J. A. Park*, H. K. Kang*, E. J. Chae*, K. S. Seo**, S. H. Kim***, C. H. Yun**** and Y. S. Moon*

Department of Animal Science and Biotechnology, Jinju National University*,

National Institute of Animal Science, RDA**, Department of Biology, Kyung Hee University***,

School of Agricultural Biotechnology, Seoul National University****

\begin{abstract}
Adipocyte-specific secretory factor (ADSF) / resistin, an hormone, is a small cysteine-rich protein secreted from adipose tissue and ADSF/resistin has been implicated in modulating adipogenesis in human and rodents. Although the exact role of ADSF / resistin in bovine has not been identified, it may have directly or indirectly involved in adipocyte differentiation. The objective of this study was to investigate its DNA polymorphism associated with carcass traits in Korean Native Cattle (Hanwoo). To investigate DNA polymorphism in Hanwoo ADSF/resistin gene, blood samples were taken from 295 Hanwoo steers belonging to progeny testing at Hanwoo Improvement Center in Korea. Seven single nucleotide polymorphisms (SNPs) were found in intron regions but not in any other regions including promoter $(1.7 \mathrm{~kb})$ and 4 exons. The highest frequency among SNPs was C186A (0.16/0.84) following G964A $(0.156 / 0.884)$. The significant correlation $(\mathrm{P}<0.05)$ between the SNPs and economic traits was found on 764Ains associated with marbling but not from any other SNPs determined. A computer simulation was also conducted to assess the efficiency of marker assisted selection (MAS) versus the conventional breeding scheme. Results revealed that MAS was more efficient as a breeding tool compared to the conventional. In conclusion, ADSF/Resistin gene is one of candidate genes to evaluate the quality, especially marbling score, in Hanwoo.
\end{abstract}

(Key words : ADSF / resistin, Hanwoo, Carcass trait, SNP)

$\begin{array}{cl}\text { I . 서 론 } & \text { 크게 변하고 있다. 연구의 최우선 목적 또한 } \\ & \text { 고기의 양적증대에서 질적 향상으로 전환을 하 } \\ \text { 최근 십 수 년 동안 한국의 쇠고기 소비의 } & \text { 고 있다. 근육 내에 침착해 있는 지방의 양(마 } \\ \text { 패턴은 고기의 양적인 면에서 질적인 측면으로 } & \text { 블링)은 육질을 결정하는 큰 요소 중 하나이며 }\end{array}$

Corresponding author : Y. S. Moon, Department of Animal Science and Biotechnology, Jinju National University, Jinju 660-758, Korea Tel : 055-751-3262, Fax : 055-751-3267, E-mail : ysmoon@jinju.ac.kr 
근육 내 지방세포의 분화가 마블링의 형성과 밀접한 관계가 있는 것으로 보고 된 바 있다 (Kawada 등, 1996). 지방세포의 분화는 섬유아 세포형인 지방전구세포가 분화되어 세포내 지 방구가 형성된 성숙한 세포로 전환되는 것으로 특징지어진다. 이와 같은 지방세포의 분화에는 형태적 변화와 동시에 분자생물학적 인자들이 관여하는데 PPARY, C/EBPa, SREBP 등의 전사 인자들과, 지방세포 특이적 유전자 및 효소 등 이 관여하게 된다(Gregoire 등, 1998). Leptin 유 전자의 발견 (Zhang 등. 1994) 이후 지방세포가 주요한 내분비 기관으로서 자리매김하였으며 최근에도 지속적으로 지방세포에서 호르몬들이 발견되고 있다 (Ahima와 Flier, 2000). 그 중 대 표적인 것 중 하나가 ADSF (adipocyte specific secreted factor)/resistin으로서 지방에서 분비되는 호르몬이면서 (Steppan 등, 2001; Kim 등, 2001) 지방대사에 관여하고 특히 지방분화와 연관이 있는 것으로 밝혀졌다 (Kim 등, 2001, 2004). ADSF/resistin은 특이적인 cysteine 반복 서열을 가진 $12.5 \mathrm{kDa}$ 의 작은 호르몬으로서 FIZZ (found in inflammatory zone)의 계열군 (family)에 속한 다 (Kim 등, 2001; Degawa-Yamauchi 등, 2003). $\mathrm{ADSF} / \mathrm{resistin}$ 의 발현은 영양 및 호르몬의 조 건하에서 조절되며 지방세포분화의 되먹임 (feedback) 조절자로 지방세포의 분화를 억제하 는 것으로 보고된 바 있다 $(\mathrm{Kim}$ 등, 2001). $\mathrm{ADSF} / \mathrm{resistin}$ 에 대한 가축의 연구가 미미한 가 운데 한우에서 이 유전자가 밝혀졌으며 설치류 와 같이 지방세포에서 많이 발현되는 것으로 보고되었다 (Kang 등, 2006). ADSF/resistin은 사 람에 있어 당뇨병 및 비만과 높은 관련성이 있 는 것으로 보고되면서 (Steppan 등, 2001) 이 유 전자의 다형성 (polymorphism)에 대하여 관심이 집중되고 있다. 그 중에서도 $\mathrm{ADSF} / \mathrm{resistin}$ 의 promoter 영역인 C-420G의 SNP (single nucleotide polymorphisms, SNPs) 경우 전사인자인 $\mathrm{Sp} 1 / \mathrm{Sp} 2$ 의 결합부위가 새로이 생성되면서 이 유전자의 promoter의 활성이 증가하게 되어 mRNA의 생 성증가와 더불어 혈중 $\mathrm{ADSF} / \mathrm{resistin}$ 의 높은 수 준을 유도함으로서 비만과 제2형 당뇨병의 위 험성을 높인다고 보고하였다 (Osawa 등, 2004;
2005). 또한 C-420G의 SNP는 대사성질환과 심 장질환 유발과 높은 상관관계가 있는 것으로 알려졌다 (Kunnar 등, 2005; Norata 등, 2007). 사 람의 ADSF/resistin 유전자의 3'UTR (untranslated region)의 exon4에서 발견된 SNP G44A의 경우 도 비만과 높은 연관이 있는 것으로 알려졌다 (Duman 등, 2007). 이 외에도 intron 영역의 $\mathrm{SNP}$ 의 발굴과 당뇨 및 비만과의 연관성을 보 고한 경우도 있다(Ochi 등, 2003; Wang 등, 2002; Engert 등, 2002). 위와 같이 사람에서는 $\mathrm{ADSF} /$ resistin 유전자의 SNP 발굴과 이의 형질 과의 연관성을 탐색하는 연구가 많이 진행되 고 있으나 경제동물을 대상으로 $\mathrm{SNP}$ 의 발굴과 경제형질과의 상관관계 연구는 거의 없는 실 정이다.

따라서 본 연구는 한우 후대검정우 295두로 부터 genomic DNA를 추출하여 지방분화에 관 여하는 호르몬 $\mathrm{ADSF} /$ resistin 유전자의 promoter, intron 및 exon 부위를 PCR 법으로 증폭한 후 이들의 염기서열을 결정하여 한우에 존재하는 단일 염기 다형성 (SNP)을 탐색하였다. 탐색된 $\mathrm{SNP}$ 들과 한우의 경제 형질들과의 상관관계 분 석을 실시하였다.

\section{ㅍ. 재료 및 방법}

\section{1. 공시축 및 genomic DNA의 분리}

DNA polymorphsim 분석을 위하여 사용 된 공시동물인 35 차 후대검정우 146두와 36차 후 대검정우 149 두에 대하여 혈액 채취 및 검정 성적을 조사하였다. 실험에는 도축 시 27개월 령의 거세한우를 이용하였으며, 도살시 항응고 제인 EDTA가 들어있는 Vacutainer (BD medical, $\mathrm{USA}$ )에 약 $5 \mathrm{ml}$ 을 취하여 $0^{\circ} \mathrm{C}$ 에 보관하였다. 이들 샘플은 Wizard genomic DNA purification kit (Promega, USA)를 이용하여 DNA를 분리하 였다. 추출한 genomic DNA는 전기영동으로 확 인하였으며 분광광도계로 농도를 확인한 후 다 음 $\mathrm{PCR}$ 의 주형으로 이용하였다. 검정 성적 조 사항목은 도살전 체중, 도체중, 도체장, 등지방 두께, 배장근단면적, 육량지수, 근내지방도, 육 
색, 지방색, 조직감, 성숙도, 육질등급, 육량등 급 및 경락단가 등 14 개 항목에 대하여 실시하 였으며 이 중 육질관련 주요 경제형질인 도체 중, 등지방두께, 배장근 단면적 및 근내지방도 에 대해서 유전능력평가를 실시하였고 이를 토 대로 $\mathrm{ADSF} /$ resistin 유전자에서 탐색된 $\mathrm{SNP}$ 들 과의 상관관계를 조사하였다.

\section{ADSF/ resistin 유전자 SNP 탐색을 위한 $\mathrm{PCR}$ 및 염기서열 분석}

한우 ADSF/resistin의 polymorphsim을 탐색하 기 위하여 본 연구실에서 NCBI genbank에 등 록한 한우 $\mathrm{ADSF} / \mathrm{rsistin}$ 의 DNA 정보 (AY618903) 를 이용하여 다음과 같이 $\mathrm{PCR}$ 을 실시하였다. ADSF promoter는 promoter forward 7 (GTT CAG AGC AAT ATC CTT GGC), promoter reverse 4 (GAA GCC CAA GCA CTG CAA CTA), ADSF exon 1- intron2는 ADSF forward 1(GAT GCC AAG GGT CTT AGC CAA G), ADSF int2 reverse (TTG GAG ATG GGC AGA GGG TCA $\mathrm{AG)}$ 를, $\mathrm{ADSF}$ intron2는 primer ADSF int2 forward (CCA CCT CTA ACT ACA GCT CAA), ADSF int2 reverse (TTG GAG ATG GGC AGA GGG TCA AG)를, ADSF intron 2-3는 primer ADSF int2 forward (CCA CCT CTA ACT ACA GCT CAA), bADSF reverse 8 (CAA GCG CAG TCT TAG GCT ACT G)를, ADSF intron3는 primer ADSF int3 forward 1(TTC AGG TAG GTA CAG AAC TCC G), ADSF int3 reverse 2 (GCA ACC AGT GTC CTG AGG AAA TG)를 각각 0.5 pmole/ $\mu \ell \quad 2.5 \mathrm{mM}$ dNTP $2 \mu \ell, \quad 10 \mathrm{X}$ reaction buffer $2 \mu \ell$, Taq polymerase 0.1 units, $\mathrm{ddH}_{2} \mathrm{O} 11.8 \mu \ell$ 의 PCR 반응물을 $94^{\circ} \mathrm{C} 5$ 분간 최 초의 변성을 시켰고, $94^{\circ} \mathrm{C}$ 30초간 변성, 52 60 ${ }^{\circ} \mathrm{C} 1$ 분간 접합, $72{ }^{\circ} \mathrm{C} 1$ 분간 확장의 3 단계 과정 을 35 cycle 순환시킨 후 마지막으로 확장단계 $72^{\circ} \mathrm{C}$ 에서 10 분간 실시하였다. 증폭된 PCR 생성 물은 $1.5 \%$ agarose gel로 전기 영동하여 밴드의 위치를 확인 하였다. 이상의 실험 산물을 PCR extraction Kit (Takara, Japan)를 이용하여 정제시 킨 후 염기서열 분석을 실시 (ABI 3100, Perkin-
Elmner) 하였고 이들 염기서열들에서 DNA 염 기다형을 탐색하기 위하여 Bioedit (http://www. mbio.ncsu.edu/BioEdit/bioedit.html) 프로그램을 이 용하여 비교 분석하였다.

\section{3. 통계분석}

(1) ADSF/resistin 유전자의 유전능력 분석 후대검정축의 유전능력은 Henderson이 제안 한 BLUP-Animal Model에 의하여 아래와 같은 모형에 의해 추정하였으며 Boldman 등의 MTDFREML package를 이용하여 각 조사형질 에 대한 육종가를 추정하였다.

$$
Y_{i j k}=\mu+Y S_{i}+L_{j}+D_{i j k}+A_{i j k}+e_{i j k}
$$

$\mathrm{Y}$; 관측치, $\mathrm{u}$; 전체 평균, $\mathrm{YS}$; 연도-계절효 과('80 '2002, 사사기, 방목기), L; 출생지역의 효과(가축개량 대사업소, 개량농가), $\mathrm{D}$; 도축일 령에 대한 co-variate, A; Random Direct Additive Effect, e; Random Error

추정된 육종가 및 표현형가와 $\mathrm{ADSF} /$ resistin 간의 연관관계 추정을 위하여 아래와 같은 모 델을 이용하여 SAS 9.1 package-GLM procedure (SAS, 2003)를 이용 분산 분석을 실시하였으며 유사한 염기서열간의 관계도 동시에 규명하고 자 분석된 염기서열에 대해 phylogenic tree를 작성하고 이를 그룹화 시켜 분석에 같이 활용 하였다.

- 표현형 모델

$$
Y_{i j k}=\mu+L_{i}+G_{j}+e_{i j k}
$$

$\mathrm{Y}$; 관측치, $\mathrm{u}$; 전체 평균, $\mathrm{L}$; 검정지역의 효과 (남원, 대관령), $\mathrm{G}$; SNP 다형성, e; Random Error

$$
\begin{aligned}
& \text { - 육종가 모델 } \\
& Y_{i j}=\mu+G_{i}+e_{i j}
\end{aligned}
$$

$\mathrm{Y}$; 관측치, $\mathrm{u}$; 전체 평균, $\mathrm{L}$; 검정지역의 효과 (남원, 대관령), G; SNP 다형성, e; Random Error 
(2) ADSF/resistin 유전자의 유전표지 탐색 을 위한 가상모형 설정

발견된 유전 표지인자에 대한 이용성을 제고 하기 위하여 computer simulation을 실시하였으 며 simulation은 호주 UNE 대학에서 개발된 genup 5.4(Brian Kinghorn, 2006) package를 이 용하였다. 고려된 종모우는 총 8 두이며 종모우 당 250 두의 종빈우를 10 년간 교배하는 모델을 작성하였다. 종빈우와 종모우의 생존율은 $95 \%$ 로 가정하였으며 평균 이유율은 $80 \%$ 로 가정하 였다. 가정한 유전표지인자 (genetic marker)의 효과는 상가적으로 발현한다는 가정 하에 $10 \%$ 로 빈도를 가질 때와 $20 \%$ 의 빈도를 가질 때를 고려하였으며 주유전자가 헤테로인 경우와 호 모인 경우 각각 없는 경우, 0.1 및 $0.2,0.2$ 및 $0.4,0.48$ 및 0.8 그리고 1,2 효과를 가질 때 10 년간 표현형의 변화치를 고찰하였다. 본 simulation에서는 근내지방도에 대한 유전표지인자를 이용하고 다른 형질에는 고려하지 않았다.

\section{III. 결과 및 고찰}

\section{1. 한우 ADSF/resistin 유전자의 단일염기 다형성 (SNP) 분석}

소의 $\mathrm{ADSF} /$ resistin 유전자는 7번 염색체에 위치에 있으며 4 개의 exon과 3 개의 intron으로 구성되어 있다. 본 연구에서는 이 유전자의 promoter를 포함하여 exon과 intron 영역의 SNP 를 탐색하기 위하여 Fig. 1과 같이 primer들을 제작하여 PCR을 실시하였다. Promoter 영역은 그 유전자의 발현을 조절하는 부위로서 전사인 자나 조절요소들의 결합에 중요한 binding site 가 있으며 이들 결합부위의 DNA 염기에 변이 가 생길 경우 그 유전자의 발현에 영향을 미칠 수가 있다 (Osawa 등, 2004; Norata 등, 2007). 따라서 promoter의 SNP 탐색은 그 만큼 중요하 다고 할 수 있다. 본 연구에서 약 $1.7 \mathrm{~kb}$ 의 promoter 영역을 클로닝한 후 SNP를 탐색한 결 과 Kang (2007) 등이 보고한 한우의 전사조절 부위의 잠정적 전사인자 결합 영역을 포함 한 어느 영역에서도 의미 있는 $\mathrm{SNP}$ 를 발견하지
못하였다. 사람 $\mathrm{ADSF} / \mathrm{resistin}$ 유전자 promoter C420G SNP의 경우 새로운 전사인자 결합부위 (Sp1/Sp2)의 생성에 의한 promoter의 활성도 증 가와 이로 인한 mRNA 발현 및 혈중 $\mathrm{ADSF} /$ resistin의 증가를 유도하고 제 2 형 당뇨병, 비만, 대사성 질환 등으로 이어져 표현형에 영향을 미쳤으나 (Osawa 등, 2005; Norata 등, 2007; Kunnar 등, 2005) 한우에서는 특이할 만한 SNP 를 발굴하지 못하였다. 그러나 본 연구에서 확 인하지 못한 promoter의 상류 (upstream)에서 $\mathrm{SNP}$ 의 출현은 여전히 배제할 수 없으며 또한 탐색한 영역일 지라도 분석되는 개체가 많을 경우 미처 탐색되지 않았던 SNP의 발견도 여 전히 관과 할 수 없다고 사료된다. 또한 exon 영역의 경우 특히 coding DNA sequence 영역은 변이가 발생할 경우 아미노산 염기서열의 변이 까지 초래 할 수 있어 SNP 탐색의 주요 관심 의 영역이다. 그러나 본 연구에서 분석한 한우 에서는 이들 exon 영역에서 SNP가 발견되지 않았다. 사람에 있어서도 비만 및 당뇨와 관련 하여 coding지역 내의 SNP는 현재까지 보고된 바가 없으며, 4번째 exon 즉, 3' UTR 영역의 $\mathrm{SNP}$ 의 경우는 비만과 상관관계가 있는 것으로 알려져 있다(Duman 등, 2007). 이와 같이 $\mathrm{ADSF} /$ resistin의 경우 종내에서 exon의 염기서 열이 매우 잘 보존되어 있음을 알 수 있다. Intron의 경우 상대적으로 promoter와 exon에 비 하여 특정 위치의 염기의 변이가 그 유전자의 발현에 미치는 영향은 상대적으로 낮으나 경우 에 따라서 특정 유전자에서는 intron의 변이가 전사에 중요한 역할을 하는 경우도 있다. 염기 서열 결정 후 분석한 결과 $\mathrm{ADSF} /$ resistin 유전 자의 intron 1 영역에서 1 개, intron 2에서 4 개 그리고 intron 3에서 2개 등 총 7 개의 $\mathrm{SNP}$ 를 발굴하였다 (Fig. 1).

한우 ADSF/resistin 유전자의 intron에서 발굴 된 SNP들의 빈도는 Table 1 에서 보는 바와 같 다. $\mathrm{SNP}$ 의 출현 빈도는 intron 1 의 $\mathrm{C} 186 \mathrm{~A}$ $(\mathrm{C} / \mathrm{A}=0.16 / 0.84)$ 가 가장 높게 나타났으며 그 다 음으로 intron 3의 $\mathrm{G} 964 \mathrm{~A}(\mathrm{G} / \mathrm{A}=0.156 / 0.884)$ 과 intron 2의 $764 \mathrm{~A}$ ins $(-/ \mathrm{A}=0.086 / 0.914)$ 가 비교 적 높게 나타났다. 그 외의 $\mathrm{SNP}$ 들은 그 빈도가 


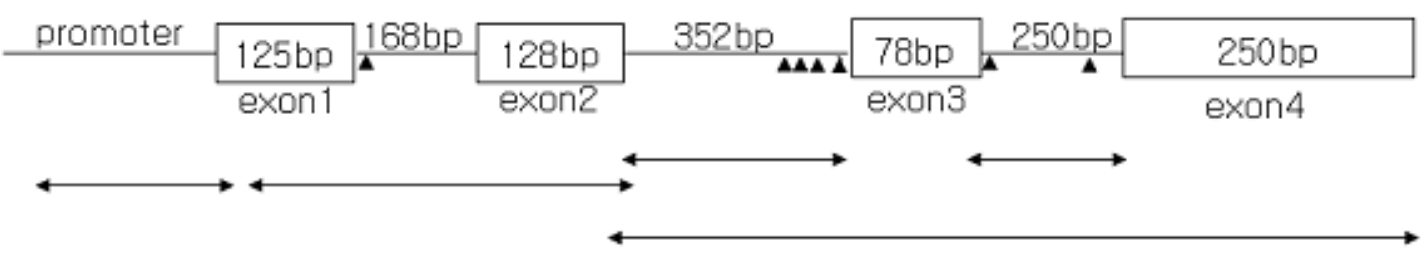

Fig. 1. A schemetic diagram of PCR regions (solid line with arrows) to identify SNPs on ADSF/resistin gene and novel SNPs (arrow heads) discovered in Hanwoo.

Table 1. Novel SNP locations and frequency of ADSF/resistin gene in Hanwoo

\begin{tabular}{|c|c|c|c|}
\hline \multirow{2}{*}{$\begin{array}{l}\text { SNP number and primers } \\
\text { for detection }\end{array}$} & \multirow{2}{*}{$\begin{array}{l}\text { SNP locations on } \\
\text { ADSF/resistin gene }\end{array}$} & \multicolumn{2}{|c|}{$\begin{array}{l}\text { Variation in Korean cattle(Hanwoo) } \\
\text { in this study }\end{array}$} \\
\hline & & Sequence & Frequency \\
\hline 1 ADSF F1 & "intron 1 (186) & C/A (C186A) & $0.16 / 0.84$ \\
\hline 2 ADSF int $2 F$ & intron 2 (756) & -/G (756G ins) & $0.038 / 0.962$ \\
\hline 3 ADSF int2F & intron 2 (762) & -/G (762G ins) & $0.027 / 0.973$ \\
\hline 4 ADSF int $2 F$ & intron 2 (764) & -/A (764A ins) & $0.086 / 0.914$ \\
\hline 5 ADSF int2F & intron 2 (767) & $\mathrm{G} /-(767 \mathrm{G}$ del $)$ & $0.027 / 0.973$ \\
\hline 6 ADSF int $3 F$ & intron 3 (964) & G/A (G964A) & $0.156 / 0.844$ \\
\hline 7 ADSF int3F & intron 3 (1214) & $\mathrm{C} / \mathrm{T}(\mathrm{C} 1214 \mathrm{~T})$ & $0.032 / 0.968$ \\
\hline
\end{tabular}

Note: SNP locations on ADSF/resistin gene (genbank accession No:AY618903) were numbered from the exon 1.

0.027 0.038로서 비교적 낮은 수치를 보였다.

\section{2. 한우 $\mathrm{ADSF} / \mathrm{resistin}$ 유전자의 SNP와 경 제형질과의 상관분석}

보다 정확한 검정 성적을 확보하고 가축의 유전 능력인 육종가 와의 상관관계를 추정하기 위하여 한우개량사업소의 후대 검정우 295두에 대하여 검정 성적을 조사하였다. 이 중 지방과 밀접한 관계가 있는 주요 경제형질인 도체중, 등지방두께, 배장근 단면적 및 근내 지방도에 대해서 유전능력평가를 실시하고 이를 ADSF/ resistin 유전자에서 발굴된 SNP와의 상관관계 를 분석하였다. 상관분석 결과 도체중, 배장근 단면적, 등지방두께 와는 발굴된 어느 SNP와도 유의성을 나타내지 않았으며, intron 2에서 발굴 된 764A ins와 근내지방도에서 유의적인 $(\mathrm{P}<$ $0.05)$ 효과가 있는 것으로 나타났다(Table 2). 발현빈도가 높았던 C186A, G964A에서는 조사 된 경제형질들과 상관관계가 없는 것으로 나타 났지만 764A ins는 발현빈도가 3번째로 높은 $8.6 \%$ 로서 그 의미가 크다고 사료된다. 사람에
게서 발견된 intron 영역의 SNP의 경우 비만과 상관관계가 있는 것으로 보고되고 있지만 인종 에 따라서 그 상관관계의 결과는 달라질 수 있 는 것으로 보고되고 있으므로 (Ochi 등, 2003; Wang 등, 2002; Engert 등, 2002; Sentinelli 등, 2002; Pizzuti 등, 2002) 타 품종의 경우 위의 결 과를 적용하기 전에 반드시 관련 부위의 $\mathrm{SNP}$ 탐색과 연관성 분석을 실시한 후에 판단을 내 려야 될 것으로 사료된다.

한우 $\mathrm{ADSF} /$ resistin 유전자에서 발굴된 SNP 중에서 $764 \mathrm{~A}$ ins가 근내지방도와 상관관계가 있는 것으로 나타남에 따라 SNP의 유전표지인 자로서의 이용성을 제고하기 위하여 컴퓨터 시 뮬레이션을 실시하였다. 본 시뮬레이션에는 근 내지방도에 대한 유전표지인자를 이용하고 다 른 형질은 고려하지 않았다. Fig. 2에서 $0.1,0.2$ 등의 수치는 유전자 빈도를 나타내며 상가적 유전자이므로 헤테로는 0.1 , 호모에서는 그 두 배인 0.2 로 표시하였다. 실제 근내지방도를 1 이 상 높이는 것은 매우 어려운 일이며 그래프에 서 볼 수 있는 전반적인 추이가 유전자 빈도가 높을수록 높아진다는 것을 알 수 있다. 사실 
Table 2. Analysis of the correlation between carcass trait and the ADSF/resistin gene polymorphism in Hanwoo

\begin{tabular}{lccccccc}
\hline Traits & C186A & 756G ins & 763G ins & 764A ins & 767G del & G964A & C1214T \\
\hline \hline CW_P & NS & NS & NS & NS & NS & NS & NS \\
EMA_P & NS & NS & NS & NS & NS & NS & NS \\
BF_P & NS & NS & NS & NS & NS & NS & NS \\
MS_P & NS & NS & NS & $*$ & NS & NS & NS \\
CW_BV & NS & NS & NS & NS & NS & NS & NS \\
EMA_BV & NS & NS & NS & NS & NS & NS & NS \\
BF_BV & NS & NS & NS & NS & NS & NS & NS \\
MS_BV & NS & NS & NS & $*$ & NS & NS & NS \\
\hline
\end{tabular}

P: Phenotype, BV: Breeding value, CW: Carcass weight, EMA: Eye muscle area, MS: Marbling score, BF: Back fat thickness

NS: No-significant *: $\mathrm{P}<0.05$.

10년은 소의 선발 및 육종에 있어 매우 짧은 시간이지만 본 연구에서 후대 검정우를 이용하 여 SNP를 탐색하였기 때문에 본 모델은 후대 검정으로 선발한다는 가정을 하였다. Fig. 2에 서 보는 바와 같이 유전자를 고려하지 않은 선 발보다 유전자를 고려하여 선발하는 것이 좋은 결과를 나타내었다. 근내 지방도의 유전력은 0.55로서 매우 높은 편이며 이에 따라 유전자
의 효과가 낮은 경우에는 유전표지인자를 이용 하여 선발한 것과 일반적인 선발 방식과의 차 이는 적은 것으로 나타났다. 그러나 유전자의 효과를 평균의 $50 \%$ 이상으로 높여준 경우에는 효과가 높은 것으로 나타났다. 반면에 주 유전 자의 빈도는 개량의 정도에 영향을 미치지 않 는 것으로 나타났다. 따라서 형질의 유전력에 따라 유전표지인자의 이용 효과가 달라지는 것

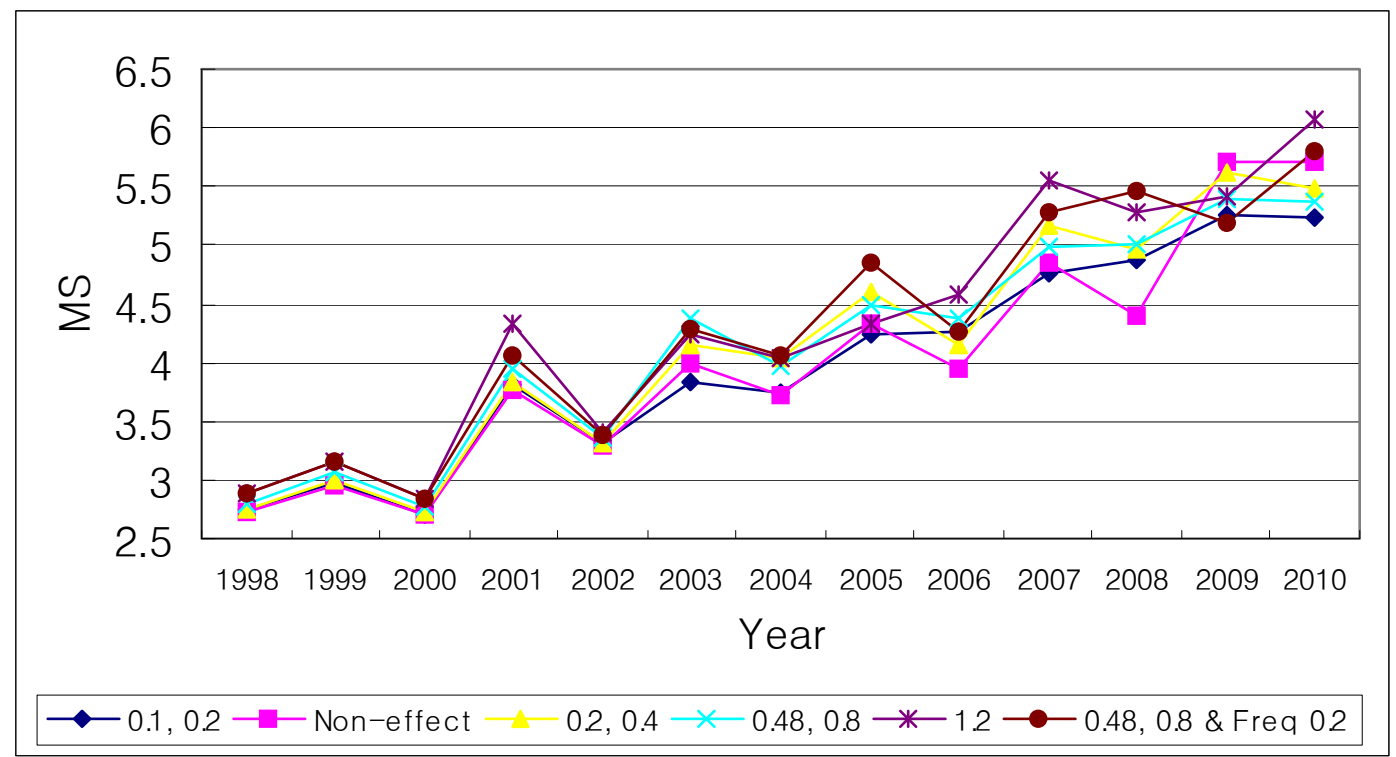

Note: Homo or hetero genetic markers (no effect, 0.1/0.2, 0.2/0.4, 0.48/0.8 and 1/2 were applied to evaluate the effect of marbling score by computer simulation (Genup 5.4 package program; Brian Kinghorn, 2006). MS: Marbling score.

Fig. 2. Genetic maker effect on marbling score by computer simulation. 
으로 사료되며 이에 따라 한우의 육질을 개량 하기 위한 유전표지인자는 그 효과가 유전력을 상회하는 정도의 효과를 가질 때 유효한 것으 로 사료된다. 그러나 2008년까지의 표현형 성 적을 고려할 때 유전표지인자를 이용한 경우가 그렇지 않은 경우에 비해 좋은 성적을 나타냈 으며 2009년에 주유전자를 이용하지 않은 경우 가 성적이 좋았던 이유는 유전적 부동(Genetic Drift)에 의한 영향으로 생각되었다. 그 증거로 2010년의 표현형 성적이 2009년과 별 차이를 나타내지 않았으며 이를 종합할 때 유전표지인 자를 이용하는 것이 근 내 지방도의 개량을 위 해 우수한 결과를 가지는 것으로 사료된다. 본 연구에서 발굴된 SNP 764A ins의 경우 추후 $\mathrm{ADSF} /$ resistin 유전자의 mRNA 발현 양상과 혈 중 호르몬 수준 등에 미치는 영향에 대한 연구 가 필요할 것으로 사료된다.

$$
\text { IV. 요 약 }
$$

본 연구는 후대검정 한우 295두의 혈액으로 부터 genomic DNA를 추출하여 PCR 방법에 의 한 증폭과 염기서열 분석을 통하여 $\mathrm{ADSF} /$ resistin 유전자의 단일염기다형을 발굴하고 이 들과 한우 육질관련형질과의 상관관계를 분석 하기 위하여 실시하였다. 확보된 DNA로부터 염기서열을 결정한 결과 promoter와 4 개의 exon 영역에서는 $\mathrm{SNP}$ 를 찾지 못하였으나 intron 영 역에서 7 개의 SNP를 발굴하였다. 발굴된 SNP 의 출현 빈도는 0.027 에서 0.16 까지 그 차이가 많았다. 육질형질과의 상관분석에서 이들 $\mathrm{SNP}$ 중 intron 2에서 발굴된 764A ins 만이 근내지 방도와 상관관계가 발견되었다 $(\mathrm{P}<0.05)$. 근내 지방도는 유전력이 매우 높기 때문에 이번에 발굴된 ADSF/resistin 유전자의 SNP 764A ins 와 같이 유전표지인자를 이용하는 것이 근내 지방도의 개량을 위해 우수한 결과를 가지는 것으로 사료된다. 가축의 경제형질의 경우 다 수의 유전자가 관여하기 때문에 한 개의 유전 자를 이용한 가축의 선발 또는 개량에 이용한 다는 것은 제한적일 수 있다. 따라서 다수의 관련 유전자를 이용한 다형현상과 경제형질과
의 연관성 연구가 동반될 때 육질개선 및 가축 개량에 실질적인 증대효과가 있을 것으로 사료 된다.

$$
\mathrm{V} \text {. 사 사 }
$$

본 연구는 한국과학재단 특정기초연구(R012006-000-10884-0)의 지원으로 수행되었습니다.

\section{VI. 인 용 문 헌}

1. Ahima, R. S. and Flier, J. S. 2000. Adipose Tissue as an Endorcine Organ. Trends Endocrinol Metab, 11(8):327-332.

2. Degawa-Yamauchi M., Bovenkerk, J. E., Juliar, B. E., Watson, W., Kerr, K., Jones, R., Zhu, Q. and Considine, R. V. 2003. serum resistin (FIZZ3) protein is increased in obese human. $\mathrm{J}$ Clin Endocrinol Metab. 88(11):5452-5455.

3. Duman, BS, Cagatay, P, Hatemi, H. and Ozturk, M. 2007. Association of Resistin Gene 3'Untranslated Region EX4-44G-->A Polymorphism with Obesity and Insulin-Related Phenotypes in Turkish Type 2 Diabetes Patients. Rev Diabet Stud. 4(1):49-55.

4. Engert, JC., Vohl, MC., Williams, SM., Lepage, P., Loredo-Osti JC., Faith, J., Doré, C., Renaud, Y., Burtt, NP., Villeneuve, A., Hirschhorn, JN., Altshuler, D., Groop, LC., Després, JP., Gaudet, D. and Hudson, TJ. 2002. 5' flanking variants of resistin are associated with obesity. Diabetes. 51(5):1629-1634.

5. Gregoire, F. M., Smas, C. M. and Sul, H. S. 1998. Understanding adipocyte differentiation. Physiol. Rev. 78(3):783-809.

6. Kang, H. K., Park, J. A., Seo, K. S., Kim, S. H., Choi, Y. J. and Moon, Y. S. 2006. Characteristics of structure and expression pattern of ADSF / resistin gene in Korean native cattle. AsianAust. J. Anim. Sci. Vol 19, No. 3:329-334.

7. Kawada, Y., Lee, S. E., Chen, C., Limson, B. M., Chan, P., Kongkanand, A., Wudhikarn, S., Tung, K. H., Rahardjo, P. and Saito, I. 1996. Evaluation 
of clinical efficacy of antimicrobials in complicated urinary tract infection. Comparison of Japanese criteria with IDSA guidelines. Infectious Diseases Society of America. Drugs. 49 (Suppl 2):362-364.

8. Kim, K. H., Lee, K., Moon, Y. S. and Sul, H. S. 2001. A Cysteinerich Adipose Tissue-specific Secretory Factor Inhibits Adipocyte Differentiation. Journal of Biological Chemistry. 276(14):1125211256.

9. Kim, K. H., Zhao, L., Moon, Y., Kang, C. and Sul, H. S. 2003. Dominant inhibitory adipocytespecific secretory factor (ADSF)/resistin enhances adipogenesis and improves insulin sensitivity. PNAS. 101(17):6780-6785.

10. Kunnari, A., Ukkola, O. and Kesäniemi, YA. 2005. Resistin polymorphisms are associated with cerebrovascular disease in Finnish Type 2 diabetic patients. Diabet Med. 22(5):583-589.

11. Norata, GD., Ongari, M., Garlaschelli, K., Tibolla, G., Grigore, L., Raselli, S., Vettoretti, S., Baragetti, I., Noto, D., Cefalù, AB., Buccianti, G., Averna, M. and Catapano, AL. 2007. Effect of the $-420 \mathrm{C} / \mathrm{G}$ variant of the resistin gene promoter on metabolic syndrome, obesity, myocardial infarction and kidney dysfunction. J Intern Med. 262(1):104- 112.

12. Ochi, M., Osawa, H., Hirota, Y., Hara, K., Tabara, Y., Tokuyama, Y., Shimizu, I., Kanatsuka, A., Fujii, Y., Ohashi, J., Miki, T., Nakamura, N., Kadowaki, T., Itakura, M., Kasuga, M. and Makino, H. 2007. The frequency of the $G / G$ genotype of resistin single nucleotide polymorphism at -420 appears to be increased in younger onset type 2 diabetes Diabetes. Aug 13; [Epub ahead of print]

13. Osawa, H., Yamada, K., Onuma, H., Murakami, A., Ochi, M., Kawata, H., Nishimiya, T., Niiya, T., Shimizu, I., Nishida, W., Hashiramoto, M., Kanatsuka, A., Fujii, Y., Ohashi, J. and Makino, H. 2004. The $G / G$ genotype of a resistin singlenucleotide polymorphism at -420 increases type 2 diabetes mellitus susceptibility by inducing promoter activity through specific binding of Sp1/3.. Am J Hum Genet. 75(4):678-686.

14. Osawa, H., Onuma, H., Ochi, M., Murakami, A., Yamauchi, J., Takasuka, T., Tanabe, F., Shimizu, I., Kato, K., Nishida, W., Yamada, K., Tabara, Y., Yasukawa, M., Fujii, Y., Ohashi, J., Miki, T. and Makino, H. 2005. Resistin SNP-420 determines its monocyte mRNA and serum levels inducing type 2 diabetes. Biochem Biophys Res Commun. 335(2):596-602.

15. Pizzuti, A., Argiolas, A., Di Paola R., Baratta, R., Rauseo, A., Bozzali, M., Vigneri, R., Dallapiccola, B., Trischitta, V. and Frittitta, L. 2002. An ATG repeat in the 3'-untranslated region of the human resistin gene is associated with a decreased risk of insulin resistance. J Clin Endocrinol Metab. 87(9):4403-4406.

16. SAS. institute, 2003. SAS/STAT user's guide: Statistics, version 9.1. SAS Instatute Inc. Cary, NC.

17. Sentinelli, F., Romeo, S., Arca, M., Filippi, E., Leonetti, F., Banchieri, M., Di Mario U. and Baroni, MG. 2002. Human resistin gene, obesity, and type 2 diabetes: mutation analysis and population study. Diabetes. 51(3):860-862.

18. Steppan, C. M., Bailey, S. T., Bhat, S., Brown, E. J., Banerjee, R. R., Wright, C. M., Patel, H. R., Ahima, R. S. and Lazar, M. A. 2001. The hormone resistin links obesity to diabetes. Nature. 409(6818):307-312.

19. Steppan, C. M. and Lazar, M. A. 2002. Resistin and obesity- associated insulin resistance. TRENDS in Endocrinology \& Metabolism. 13(1):18-23.

20. Wang, H., Chu, WS., Hemphill, C. and Elbein, SC. 2002. Human resistin gene: molecular scanning and evaluation of association with insulin sensitivity and type 2 diabetes in Caucasians. J. Clin Endocrinol Metab. 87(6):2520-2524.

21. Zhang, Y., Proenca, R., Maffel, M., Barone, M., Leopold, L. and Friedman, J. M. 1994. Positional cloning of the mouse obese gene and its human homologue. Nature 372:425-432.

(접수일자 : 2007. 8. 30./ 채택일자 : 2007. 10. 15.) 